\title{
Health care network (dis)articulation in late and moderate prematurity
}

\author{
(Des)articulação da rede de atenção à saúde na prematuridade tardia e moderada \\ (Des) articulación de la red asistencial en prematuridad tardía y moderada
}

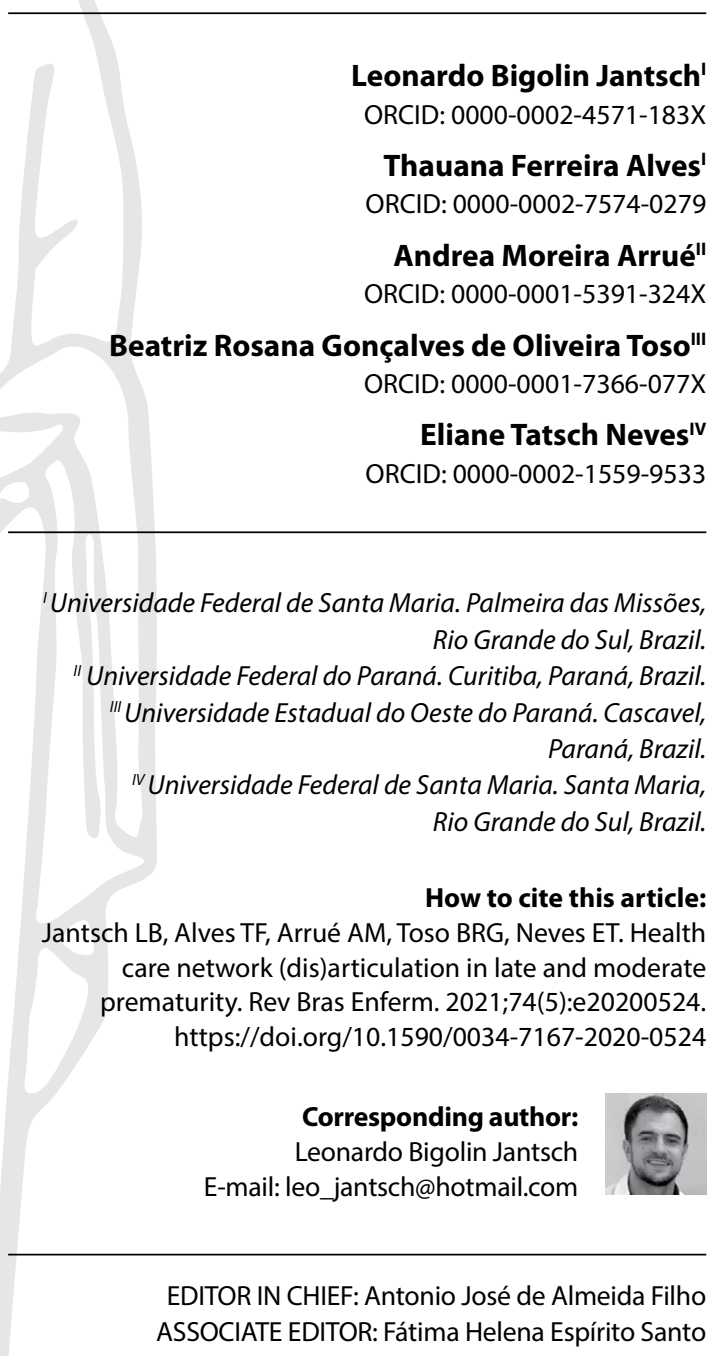

Submission: $07-01-2020$

Approval: 11-16-2020

\section{ABSTRACT}

Objective: to analyze the Health Care Network (dis)articulation of late and moderate premature infants in the first year of life. Method: a qualitative study with semi-structured interview, which addressed the care network constitution in a municipality in southern Brazil. Fifteen mothers of infants participated. Thematic content analysis and flowchart were used to describe networks and services. Results: first contact in Primary Health Care is a decisive factor for the recognition and articulation of neonates/infants in the network and enables resolution, especially in childcare demands. Secondary and hospital care services support isolated acute events or chronic conditions, without articulation between levels of care and in a uniprofessional way. Final considerations: attention to health conditions is organized and structured in a uniprofessional, fragmented and disjointed way, which makes it impossible to form a Health Care Network premature infants' perspective.

Descriptors: Infant, Premature; Health Services; Child Care; Primary Health Care; Pediatric Nursing.

\section{RESUMO}

Objetivo: analisar a (des)articulação da Rede de Atenção à Saúde de prematuros tardios e moderados no primeiro ano de vida. Método: estudo qualitativo com entrevista semiestruturada, que abordou a constituição da rede de atenção em um município no sul do Brasil. Participaram 15 mães de lactentes. Utilizou-se análise de conteúdo temática e fluxograma para descrição das redes e serviços. Resultados: o primeiro contato na Atenção Primária à Saúde é fator decisivo para reconhecimento e articulação do neonato/lactente na rede e possibilita resolutividade, em especial nas demandas de puericultura. Serviços de atenção secundários e hospitalares oferecem suporte a eventos agudo isolados ou às condições crônicas, sem articulação entre os níveis de atenção e de forma uniprofissional. Considerações finais: a atenção às condições de saúde se organiza e se estrutura de forma uniprofissional, fragmentada e desarticulada, o que impossibilita a formação de uma Rede de Atenção à Saúde na perspectiva desses prematuros.

Descritores: Recém-Nascido Prematuro; Serviços de Saúde; Cuidado da Criança; Atenção Primária à Saúde; Enfermagem Pediátrica.

\section{RESUMEN}

Objetivo: analizar la (des)articulación de la Red de Atención de la Salud del prematuro tardío y moderado en el primer año de vida. Método: estudio cualitativo con entrevista semiestructurada, que abordó la constitución de la red de atención en un municipio del sur de Brasil. Participaron quince madres de bebés. Se utilizaron análisis de contenido temático y diagramas de flujo para describir redes y servicios. Resultados: el primer contacto en Atención Primaria de Salud es un factor decisivo para el reconocimiento y articulación del recién nacido/lactante en la red y permite la resolubilidad, especialmente en las demandas de atención infantil. Los servicios de atención secundaria y hospitalaria apoyan eventos agudos aislados o afecciones crónicas, sin articulación entre niveles de atención y de manera no profesional. Consideraciones finales: la atención a las condiciones de salud está organizada y estructurada de manera uniprofesional, fragmentada y desarticulada, lo que imposibilita la conformación de una Red de Atención a la Salud desde la perspectiva de estos prematuros. Descriptores: Recién Nacido Prematuro; Servicios de Salud; Cuidado del Niño; Atención Primaria de Salud; Enfermería Pediátrica. 


\section{INTRODUCTION}

The health care model, in addition to its different conceptions, is assumed here as a logical system that organizes the functioning of services, including their organization through Health Care Networks (RAS - Redes de Atenção à Saúde). RAS, in turn, uniquely articulate the relationships between the subpopulations stratified by risks, the focus of interventions in the care system and the different types of health interventions, defined according to the prevailing view of health, demographic and epidemiological situations of the social determination of the health-disease process ${ }^{(1-2)}$.

As a consequence of social determination in the child's health, premature birth is considered a risk factor for healthy growth and development, being a trigger for chronic health conditions. About $10 \%$ of those born in Brazil are premature; of these, $84 \%$ enter the age range of borderline prematurity (32 to 36 weeks and 6 days of gestational age (GA)). Children born within the range of borderline prematurity, as well as extreme premature infants, have a history of clinical fragility and social vulnerability, tending to have developmental and growth problems, in addition to developing acute and chronic health conditions ${ }^{(3)}$.

Many of these children, considered to be newborns (NB) almost at term, exhibit school difficulties, in addition to showing worse motor repertoire, behavior problems and growth alterations, when compared to children born at term ${ }^{(4)}$. Prematurity is a public health concern that directly implies the child's clinical conditions and the appearance of risk factors for infant morbidity and mortality. Even though late preterm infants do not demand greater health demands from Primary Health Care services, they are more frequent in the services ${ }^{(5)}$.

Moreover, the context of prematurity involves different causalities that interact with each other and affect different populations, in processes that favor the emergence of chronic diseases ${ }^{(6)}$. Depending on the way the therapeutic itinerary is followed, care can be weakened and fragmented, making RAS ineffective to meet the needs of this patient ${ }^{(7-8)}$.

Attention to chronic conditions in childhood, including prematurity, requires care that respects the singularities that may be (in)visible to the promotion of actions in different periods of the disease and/or condition. Thus, it is necessary that RAS and their professionals are motivated and aware of their demands $s^{(9-10)}$.

In addition to the organization of RAS to meet acute and chronic demands, health systems may have little or no integration between RAS entities, fragmenting health care. Fragmentation's perspective permeates the processes in which each level of care works in isolation, is resolving only for the moment, and thus emphasizes acute demands $\mathrm{s}^{(1)}$.

In this perspective, it is highlighted that, with regard to chronic childhood diseases/conditions, they are not included in policies for care for the chronically ill. However, the constitution of RAS is recommended, and Primary Health Care (PHC) should be a

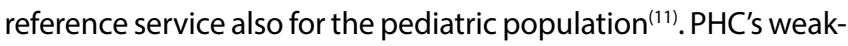
ness in recognizing the health demands of premature infants is recognized as it is the tip of the network, acting in a reactive, outpatient, fragmented and focused on children's diseases. The "pilgrimage" of premature infants in RAS and the gap in training and preparation of teams to identify premature infants' needs, in Family Health (FHt) teams, are characteristics that weaken monitoring the therapeutic itineraries of premature infants and their family, which distances PHC best practice ${ }^{(12)}$.

In this context, understanding the organization of health networks to include care for late and moderate preterm infants, through their health demands, directly contributes to: transfers from families after hospital discharge; recognition of the transfer and support needs of the health team and specifically nursing; orientation to PHC services, which, in theory, should welcome them under their care.

\section{OBJECTIVE}

To analyze the Health Care Network (dis)articulation of late and moderate premature infants in the first year of life.

\section{METHOD}

\section{Ethical aspects}

The research project was approved by the Research Ethics Committee of Universidade Federal de Santa Maria, respecting Resolution 466/2012. Participant anonymity and discretion are guaranteed by means of the letter $P$, followed by a numerical sequence (P1, P2, P3...P15).

\section{Type of study}

This is a descriptive-exploratory study, with a qualitative approach arising from a mixed doctoral thesis, guided by the convergent parallel strategy. The methodological presentation of the present study, with a qualitative approach, was based on the COnsolidated criteria for REporting Qualitative research $(\mathrm{COREQ})^{(13)}$ and the RAS theoretical framework ${ }^{(1)}$ for data analysis.

\section{Study setting}

The study scenario was a municipality in southern Brazil, in which RAS is distributed in Basic Health Units and Family Health Strategy, Specialized and Complementary Services, Health Surveillance Service, Municipal Child and Adult Emergency Service, Emergency Care Unit (ECU) and public and private hospitals. This distribution comprises: 16 teams of Family Health Strategies, arranged in 13 physical structures; 17 Basic Health Units; 04 Psychosocial Care Centers (CAPS - Centros de Atenção Psicossocial), in addition to support services. About $60 \%$ of the population is covered by a Basic Health Unit ${ }^{(14)}$.

\section{Data source}

Mothers of infants (they were considered the main caregivers of infants, in the family's perception) who were born between May 2016 and May 2018, with GI in the period of 32 to 36 weeks and 6 days, considered borderline premature infants participated in the study. The group classified as late preterm comprised those born at 34 to 36 weeks and 6 days of GA; the moderate premature group comprised those who were born with 32 to 33 
and 6 days of $\mathrm{GA}^{(15)}$. Infants who lived in the city of Santa Maria, $\mathrm{RS}$ were included.

The initial selection of participants, in the quantitative stage, took place at the Obstetric Center through the birth registration book. The selected population to be followed was 151 preterm infants, however, in the qualitative stage, 15 participants were selected for the interviews. The selection of participants in the qualitative stage was for convenience, with the inclusion of participants who developed chronic and acute health conditions, as well as the participation of moderate and late preterm infants in the same proportions. Data production closure occurred as theoretical density ${ }^{(16)}$ was obtained, considering it sufficient to answer the objective of the study.

\section{Data collection and organization}

Data were produced through semi-structured interviews following a script built from PHC attributes ${ }^{(17)}$. The script contained questions about access to services, transfer, resolution, coordination of care, affiliation among other PHC attributes ${ }^{(17)}$. In this perspective, RAS analysis was built from the perception and experience of the mothers of these infants. The interviews were scheduled by prior contact with the researcher and took place at the participants' homes, considering the best day and time for these. The interviews were conducted by the researcher and a research assistant with the main family caregiver in the households, with an average duration of 20 minutes per interview (minimum 15 min and maximum 32 minutes). The interviews were recorded using an electronic recorder, and later transcribed in a Word document for analysis, under double review of the transcription, i.e., the audio was transcribed by research assistants (one academic and three medical scholars with scientific initiation scholarships) and reviewed in full by the researcher.

\section{Data analysis}

The interview transcripts constituted the data analysis corpus, in which thematic content analysis was used, given by the stages of pre-analysis, coding and analytical interpretation ${ }^{(18)}$. In the pre-analysis, the first contact was made with the material transcribed from the interviews where a thorough reading of data, and familiarization with raw data allowed to guide initial analytical possibilities under the perspective of RAS and health conditions theoretical frameworks. In coding, after sequential and exhaustive reading, it was possible to identify words or expressions, recurrent and highlighted in the statements, that would guide the contextualization and description of graphic flowcharts, representative of RAS and health conditions of premature infants. Finally, to give meaning to the objective of the investigation, the interpretation of this analytical construction started from the theoretical and analytical framework of health conditions and $\operatorname{RAS}^{(1)}$. For the geographic presentation of RAS and participants' clinical characterization, some diagrams and specific codes were used (defined by the recurrence of words and expressions of participants, defined in the coding stage), as shown in Chart 1.
Chart 1 - Description of the symbols used in the characterization of the care network of moderate and late preterm infants in the first year of life, Santa Maria, Rio Grande do Sul, Brazil

\begin{tabular}{|l|l|}
\hline MEDICAL CHILD CARE follow-up \\
\hline
\end{tabular}

\section{RESULTS}

The interviews took place for six participants in the third month of life, for five participants in the sixth month and for four participants in the ninth month of life. Of the 15 participants, 12 (80\%) were late preterm infants, nine $(60 \%)$ were female, ten $(67 \%)$ were born with adequate weight for GA, six (40\%) had chronic health conditions and socioeconomic classes $C$ and $D$ were the most frequent $(n=11,73 \%)$.

Service analysis starts from the demand classified as chronic demand, isolated acute or worsening of the chronic condition. In the following figures, the RAS of three participants will be presented, elected to represent, synthetically, the 15 interviewees. In the figures below, there is participant characterization [routine demands (childcare, vaccine, etc.), chronic and acute], as well as a description of the health services that they accessed or should access from demands. Figure 1 shows $\mathrm{P} 1$ characterization. 


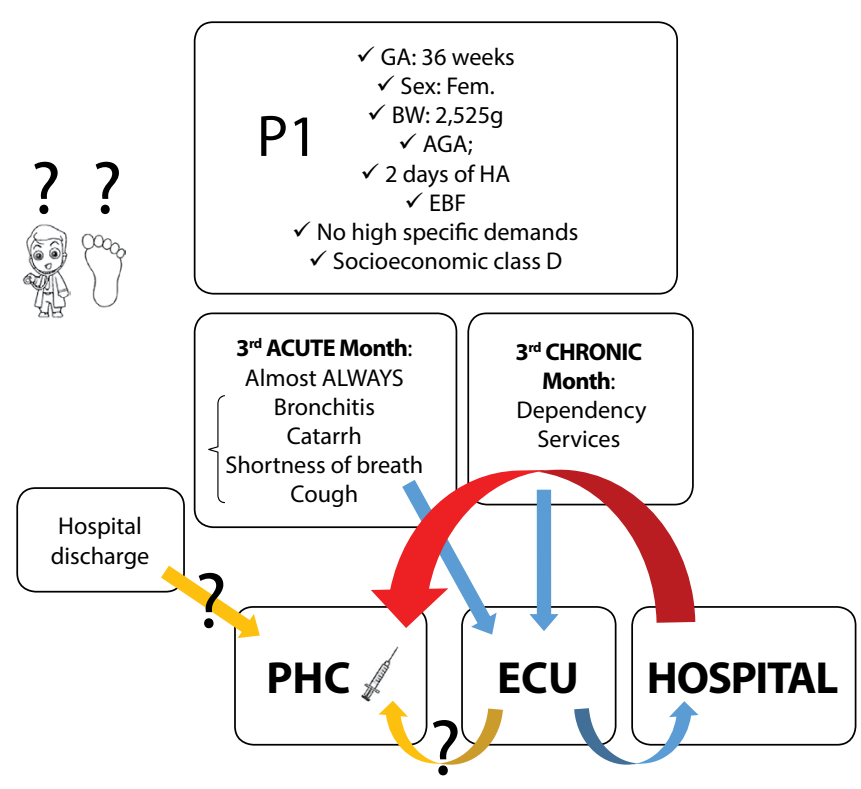

Notes: GA - Gestational Age; Fem. - Female; BW - Birth Weight; AGE - Adequate for Gestational Age; HA - Hospital Admission at birth; EBF - Exclusive Breastfeeding; PHC - Primary Health Care; ECU-Emergency Care Unit.

Figure 1 - Description of service flows, care network and health demands of P1 in the third month of life, Santa Maria, Rio Grande do Sul, Brazil 2018

Through analysis of RAS and P1's health demands, the weakness of the first access is highlighted, with a questionable transfer, with no possibility of access to PHC service, since the child did not present specific demands at hospital discharge or that require specialized service. The ECU secondary care service was the reference for acute and chronic health demands, justified by the statement:

Because they $[\mathrm{PHC}]$ do not assist us, there is no physician, there is only a nurse. Then they send it to the ECU for anything. (P1)

The statement portrays the weakness of $\mathrm{PHC}$ for health demands and the transfer to secondary care services, justified by being a local with the existence of a medical professional/pediatrician. There was a "theoretical"transfer from an ECU to a PHC through a verbal reference:

The only thing they tell you to do is treatment at a health center, consult with a pediatrician, always take them to see her, but I don't have it here in the neighborhood and nowhere. (P1)

The hospital, which received a child's hospitalization due to an acute health event in the third month of life, through referral to emergency service, ends up, in turn, not transferring the child to PHC. As for centralization and main reference to outpatient service, P5's RAS, moderate premature infant, is described in Figure 2.

The description of access to services and how it is organized through acute and chronic demands in the third month is limited to accessing the specialty clinic, with post-discharge access, presenting itself as a reference service for acute and chronic conditions. PHC appears "only" as a possibility to monitor childcare and a reference for vaccination. Still, in this perception, the figure of the physician is the only member of the team with whom the mother has "confidence". The justification reported by the mother due to different behaviors from other professionals was that the NB was considered vulnerable due to prematurity.

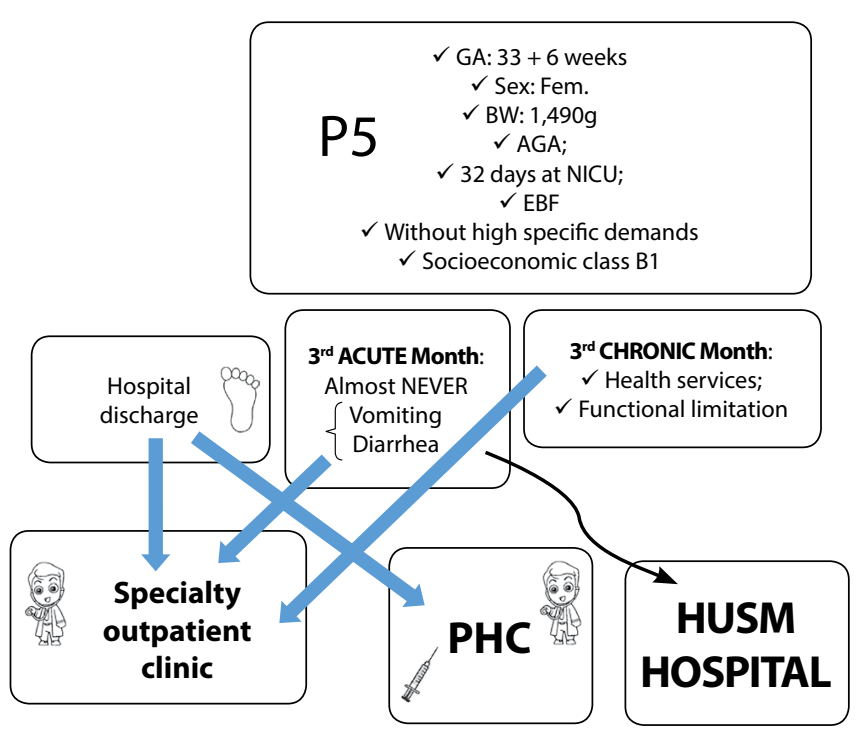

Notes: GA - Gestational Age; Fem. - Female; BW - Birth Weight; SGA - Small for Gestational Age; NICU-Hospitalization in a Neonatal Intensive Care Unit; EBF - Exclusive Breastfeeding; PHC - Primary Health Care; HUSM - Hospital Universitário de Santa Maria [reference hospital/high complexity]. Figure 2 - Description of service flows, care network and health demands of P5 in the third month of life, Santa Maria, Rio Grande do Sul, Brazil

In follow-up, only [physician's name] weighs her! He weighs himself, he measures, he looks at her, he [...] only he does not meddle in the things that were prescribed by the [Premature Outpatient Clinic]; in fact, she is going more just to know that she exists in the community, because she exists, as she is also doing follow-up there [Premature Outpatient Clinic], every prescription is from there, so if she is breastfeeding, she is gaining weight, she has color, she is fine you know, so l'm not going to, you know, change the conduct, from [name of hospital]. (P5)

They [nursing staff] weighed her, and 1,700 [grams] were registered here at the unit. I went into shock, left in despair, that was on Tuesday, then on Thursday she had an appointment at [name of hospital] and I looked at her and said "but she is so round" [...] there at the [Premature Outpatient Clinic] we arrived and weighed it and it was 2,400 [grams], then you see how much I cannot trust, they wrote it down on their card. The other day I went there to talk, then they wrote a letter saying that the scale was damaged, but I never let them [the nursing team] touch it again, they can't go wrong with a premature infant. (P5)

PHC brings an experience of the mother's daily life related to socioeconomic and cultural contexts. This makes care closer, and communicating the service with users is essential. This perception of cultural practice to the practice of care is perceived in the discourse, in addition to those constructed from the experiences and from what worked.

Here [PHC] I felt more free to talk about it [care practices] here at the health unit, because the experience with the physician's community, here in the community, is greater than the one there [Specialty Clinic], because when I/ told the [Outpatient Resident Physician] the method [Offering breast milk expressed by the bottle] that I was making for her, since I saw that she was not sucking wonderfully in the chest, and [the PHC physician] authorized it, he said that I was wrong, he said that I should continue to give only the breast, that I should insist even if she 
slept , I was supposed to keep insisting, because he told me it was not right to offer a bottle, so I was really angry, I was furious! Even my mother was at the consultation and I said, "90\% of those women out there, who have premature infants like [child's name], none are giving breast milk, I was the only one who was giving it to my daughter and does he come to tell me that I'm wrong?" I left the appointment and went to milk because it was all wet with milk. (P5)

Discussing these successful practices strengthens the network and gives credibility to health services. Articulation between services should happen; however, different practices are established, and cultural aspects of what worked out become a priority for the mother. The best weight gain, after adopting this practice and the reduction in the number of feedings, milking and offering it in a bottle was an accessible care practice in which a child was gaining weight and there was no need to remove the role of sucking the breast.

Regarding the description of a service network centered on PHC, P15's RAS stands out, represented in Figure 3.

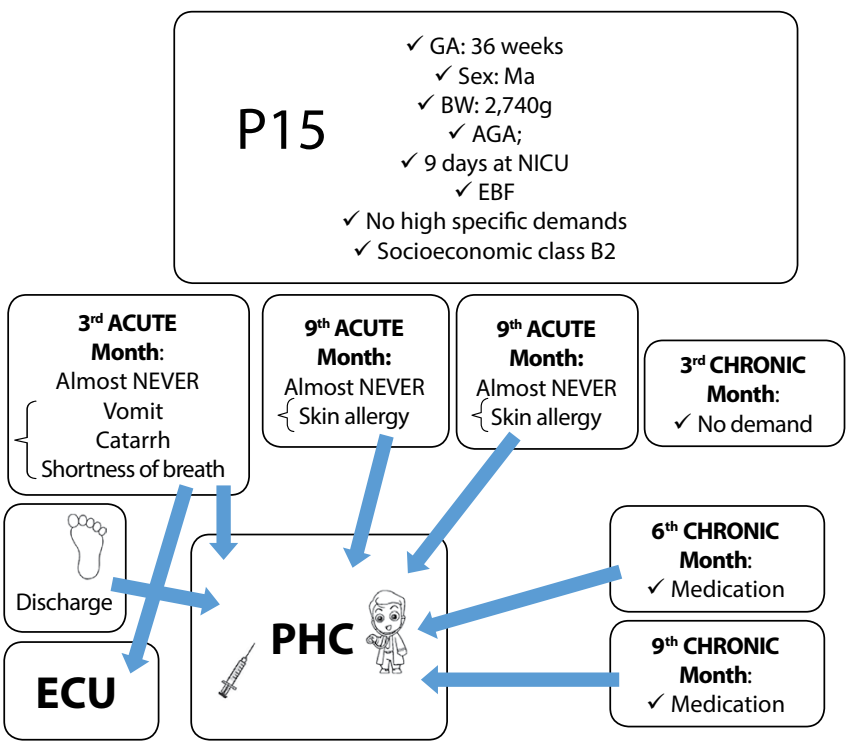

Notes: GA - Gestational Age; Ma.- Male; BW - Birth Weight; AGA - Adequate for Gestational Age NICU - Neonatal Intensive Care Unit; EBF - Exclusive Breastfeeding; ECU - Emergency Care Unit; PHC - Primary Health Care.

Figure 3 - Description of the flows of services, care network and health demands of P15 in the first year of life, Santa Maria, Rio Grande do Sul, Brazil

Under analysis of flow description, in P15's RAS, up to the $9^{\text {th }}$ month of life, even with chronic demands established by the use of medicines, access occurred in PHC service. It is noted that the initial transfer to PHC happened after discharge from NICUs (Neonatal Intensive Care Units). Follow-up took place and the service was a reference for acute and chronic demands, especially for skin allergy demands and the need for chronic medication use. Regarding the characterization of access and maintenance of these services, P9 and $\mathrm{P} 10$ represent, in a representative way, their references in health services and the first access through the statements:

My referral health center is [name of BHU], but I am not going there because there is no pediatrician and it is not very easy to get an appointment, I am going a long way, there in [name of another $\mathrm{BHU}$ ], in [neighborhood], that I get everything there, pediatrician; time to make an appointment is at one o'clock in the afternoon, so it's very quiet. It's very interesting, because there I don't need to wake up too early to get a record, just go there and book. There they follow everything about her, growth, these things and also her allergy problems, that she makes use of the medicines that the physician there gave [...]. Whenever she feels sick, I take her there, if I have to take her all the time, I will do it, in fact the ECU is much closer, so I try to avoid it, because if the child has a beak [pacifier], he [pediatrician] doesn't assist us, then I take her to the municipal emergency department, it takes a long time to get there, but sometimes you leave and they even give you a medicine. (P9)

I was instructed when he completed seven days to go to the nearest health center. However, the health center does not have a pediatrician yet, but a nurse who does the consultation every time [...] she monitors, weighs, measures, sees if there is anything different to send to the physician [...]. He's always sneezing. I went to the nurse and she told me to put saline solution on his nose and everything, she already knows him, right, so it's easier to know what's normal about him or not. Só que essa tosse se prolongou até os dois meses. When he went to get the two-month vaccine, I met this nurse at the clinic and asked if it was normal for him to have this runny nose and everything else, she said to look for an emergency service, they were without a physician, then last week she attacked and he was hospitalized five days [...] it started with an increasingly strong cough and a lot of cough, then I said "no, this is not right, it must be some allergy". Then I went to the emergency room, an X-ray was done, the physician examined it and everything and at first it was just a virus. (P10)

Access to $\mathrm{PHC}$ is also the reference for acute conditions of P14 and $\mathrm{P} 15$, without presenting chronic health conditions, accessing the $\mathrm{PHC}$ service as a reference service, justified by the statements:

At the health center, I had an appointment after ten days of her birth. I was able to consult with the pediatrician once, then the nurse accompanies her, who measures, weighs and asks if everything is fine! I had to take her in an ECU a couple of times because she was very congested, panting, it looked like she was out of breath, so the physician evaluated there, gave her a serum to wipe her nose and released it, she got better! I like it there [PHC], the girls [nursing staff] know her. (P14)

I usually consult there at the health center to accompany her. The physician takes a look at her, especially her allergies and sometimes I look there [PHC], too, when I need something that is not too serious, so I take her there, nurses [nursing staff] take a look at her, evaluate if you need to see the physician, otherwise I take her in an ECU, when it is more serious. (P15)

There is a similar characteristic in the four care networks mentioned above, which is the effective access at hospital discharge and the maintenance of the service's bond with childcare and monitoring. The service that becomes a reference for childcare also ends up becoming a reference for the child's acute and chronic health demands. The feeling of trust in the service was implicit in the statements, mainly due to professionals' monitoring and knowledge of the child's clinical condition, reinforcing the maintenance and search for the service. 
The monitoring of chronic conditions was well established in P13's RAS. The child developed cerebral palsy as a result of ventricular hemorrhage during hospitalization. There were 22 days of hospitalization, and referral of this child to a premature outpatient clinic was established.

In short, starting from analysis of the 15 interviews, service description and RAS (dis)articulation are observed in Figure 4.

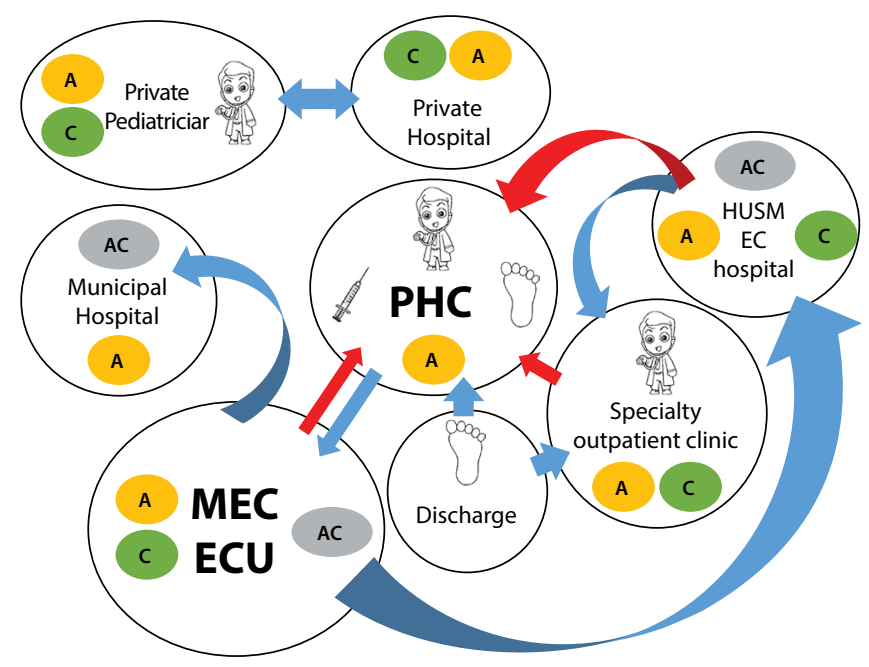

Notes: PHC - Primary Health Care; HUSM EC - Hospital Universitário de Santa Maria Emergency Care [reference hospital/high complexity]; MEC-Municipal Emergency Care;ECU-Emergency Care Unit Figure 4 - Synthesis of the organization and relationships of services in the health care network of moderate and late preterm infants in the first year of life, Santa Maria, Rio Grande do Sul, Brazil

Based on this analysis, in Figure 4, the outcome and demand for health services can be characterized under five possibilities:

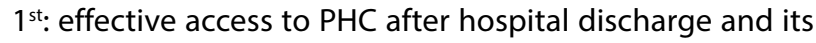
maintenance in the service as a reference point for childcare and resolution for some acute conditions and referral to secondary and tertiary services (when necessary); it is noticed that PHC is not an access service for chronic conditions, very centralized in the specialized service in a hegemonic way;

$2^{\text {nd: }}$ access after PHC discharge from premature infants is a decisive factor in maintaining the bond of this child in this service and maintaining it as the main reference service. $\mathrm{PHC}$, for those who had the correct transfer and the first contact existed, is considered a problem-solving service for prematurity' demands in the first year of life;

$3^{\text {rd: }}$ : the absence of an effective transfer to PHC at the time of hospital discharge is related to: the lack of childcare follow-ups; the isolated treatment of acute conditions in urgent and emergency services; failure to recognize/diagnose chronic conditions; the treatment of the worsening of these chronic conditions in secondary and tertiary services;

$4^{\text {th }}$ : the use and effectiveness of private health services (private pediatrician and hospital network) to resolve acute and chronic conditions as well as childcare;

$5^{\text {th }}$ : for those with early definition of a chronic condition (hospital discharge), there is a centralization of health care for the medical specialty outpatient service, especially for chronic conditions, and the lack of a connection with PHC, in this case.

\section{DISCUSSION}

It is recommended that every NB, after hospital discharge, have their first follow-up visit in the first week of life, since it is the period of adaptation of the family with their infant to a new social and biological condition. During this period, it is recognized that the evaluations of first consultation guide childcare guidelines, establishing family demands, based on this new family member, and infants' biological demands ${ }^{(19)}$.

Guidance for consultation in the first week is essential for all NB; however, there are some special conditions that require special attention. Among these conditions, the following stand out: prematurity, low weight, Apgar less than 7, low education, more than 3 children in the same household, non-exclusive breastfeeding, low socioeconomic status, high-risk pregnancy, among other conditions ${ }^{(19)}$, present in the studied population.

This recommendation, highly highlighted in ministerial manuals, requires a service response in a structured (need for physical structure and human resources) and organized (relationship and communication between health services) so that RAS can be thought out and constituted. There is an undeniable need for monitoring to take place in the first days. Many children in this study were discharged, especially moderates, with specific demands, such as weight control and the use of medications that require support from the network. Premature infants with GA of 34 to 36 weeks of gestation, according to a national study, attend PHC services more when compared to those born at term. This fact is justified by the family's concern given the early birth ${ }^{(5)}$.

The greatest demands of parents of moderate and late preterm infants in post-hospital discharge period are in the relationship of trust (support from the social and professional network) and access to support services, which are no longer the hospital and NICUs, previously a reference. It is at this moment that the bond needs to be created, especially for those not transferred to specialized outpatient clinics for premature infants ${ }^{(20)}$.

In the findings of this study, it is clear that, at hospital discharge, transfer is registered, i.e., there is a theoretical referral of these children to PHC as the main reference service. The "theoretical" referral is defined here as a record in a medical record that referral was directed to mothers. However, the structuring obstacles ["there is no pediatrician" (P1)] make this first contact impossible. The absence of this weakens the first PHC attribute and the possibility of being a reference in health for the demands generated by prematurity or other conditioning factors.

Premature children, regardless of their GA, with low birth weight, particularly those discharged to socially vulnerable families, should receive attention from RAS, and home visits can be considered an effective strategy. Much is spent on these children to keep them alive in NICUs, and it seems to be a wise investment to support home visits and family medicine to try to optimize the health and well-being of these children after discharge $\mathrm{e}^{(21-22)}$.

Some factors are justified for the difficulty of access and maintenance of the child in PHC services, such as: organization of services with regard to the days and hours of care; scheduling and number of consultations with the team; reduced number of professionals that make up the interdisciplinary team; great spontaneous demand in the context of PHC as well as outpatient clinics ${ }^{(23-24)}$. 
According to global situation, a study carried out with countries in southeastern Asia highlights that access to PHC or to followup, neonatal and puerperal consultations have a decisive and discriminatory economic influence. The international scenario recognizes the important role of $\mathrm{PHC}$ in child health, but emphasizes that it has been neglected in many countries in favor of a disease-specific and hospital-oriented approach, probably due to a lack of political will and underinvestment. in health infrastructure and workforce ${ }^{(25)}$.

Maintaining the bond of preterm infants, especially the extremes, in PHC and in post-discharge follow-up, occurs through accountability, intersectoriality, technical-scientific knowledge of professionals and the development of favorable public policies. These reflexes portray and corroborate the findings of this study as the (i)responsibility for the concrete transfer of premature infants reflects in their first absent access. The lack of scientific and technical knowledge, specific about the growth and development of premature births, implies in many cases, the lack of trust of parents to maintain the bond in the service ${ }^{(26-27)}$. The team of preterm follow-up clinics linked to these children's birth hospitals could optimize referral and counter-referral with the care network, stimulating the bond, a fact that was not demonstrated in the statements.

Studies corroborate the description of the network found in this study for premature births as less than half of premature infants remain in RAS. The main problems of lack of adherence are the lack of immunization, the absence of preventive care guidance for age and the fragile bond with $\mathrm{PHC}$ professionals for follow-up and timid referral and counter-referral ${ }^{(26-28)}$. It is understood that PHC should be the point of attention in the health system that offers entry to that system for needs and problems, providing care for people and their families over time and in all conditions. Thus, consolidating access to the range of health activities and services, at this level of care, requires the dismantling of barriers that prevent access ${ }^{(17)}$.

The structuring of the systems, identified in this RAS for moderate and late preterm infants, suffers a predominance of a model centered on the biological and the figure of the physician. This characteristic is intertwined with the needs expressed by children and their families, who seek medical care in PHC, while other professionals are available for care, such as nurses. Families have divergent interests, characterized by a model of medicalization and healing, that is, when the figure of the physician is non-existent in the primary service, she is sought in emergency services ${ }^{(23)}$.

Thinking about PHC structuring is thinking about its reflection for organization of services and RAS. It was found that there are no other professionals in the services, or ignorance of their demands, to meet and be resolute to the demands of premature infants. This finding was identified as professionals transfer/send premature infants from their health service, often without even knowing their demands. In places where the first contact took place effectively and the maintenance of the bond focused, the participation of nurses as professionals responsible for childcare and responsibility for premature infants' health stands out. According to participants' testimonies, the role of nurses in maintaining the bond in PHC services and resolving health demands made them become reference professionals for these families. These statements recognize that the demands of these premature infants allow them to be welcomed by nurses, since they organize RAS articulation, also being responsible for the effective access in other health services.

Some studies highlight the leading role of nurses in care and maintenance of premature infants' bond. It is recognized that in addition to monitoring and resolving the acute demands and clinical manifestations of preterm infants, they are responsible and considered facilitators of the process of building family autonomy in the care of preterm infants after hospital discharge ${ }^{(27-28)}$. Weaknesses in RAS and in mechanisms for monitoring preterm infants and those discharged from neonatal units and the gaps in integration and continuity of care generate more vulnerabilities for children and their relatives who already exist in fragile physical and psychosocial circumstances ${ }^{(29)}$.

For prematurity's demands, especially in the first week of life, as well as in the reference for childcare and in acute and chronic demands, $\mathrm{PHC}$ can be considered a reference service. To this end, there are some obstacles that require proactive responses from services that are established by their attributes. These findings corroborate and provide discussions about the possibilities of structuring and organizing RAS, having it as a network coordinator in the perspective of improving premature infants' health condition.

\section{Contributions to nursing and public policies}

The implications of this study for practice refer to the importance and need for the effective and qualified transfer of these premature infants, regardless of GA, to PHC services. It is a decisive factor for this child to be included in the network and their demands can be recognized, met and resolved. Moderate and late preterm infants have specific health demands, especially associated with weight gain and greater acute health problems. These findings imply the definition of $\mathrm{PHC}$ as a service that coordinates the network.

\section{Study limitations}

As a limitation of this study, aspects related to the description of a local reality, which cannot be generalized, and from the perspective of local care offers and demands, as well as the differences and clinical outcomes that may occur within the age group 32 to 36, are understood 6-day weeks and no comparison with full term or premature infants.

\section{FINAL CONSIDERATIONS}

First access of moderate and late preterm infants to health services in PHC is fragile/non-existent and can be considered a decisive factor in maintaining programmatic monitoring in services. Premature infants who, to a lesser extent, accessed these services effectively, after hospital discharge, developed programmatic care through childcare, which allowed the construction of RAS coordinated by PHC. In cases where this level was not a reference/ effective after hospital discharge, health care was not articulated in a network, since most gateway to health services happened by 
emergency services, which attend, in a fragmented way, acute aggravations or worsening of chronic conditions.

Attention to health conditions is organized and structured in a uniprofessional way, centered exclusively on the figure of the physician, fragmented and disjointed, which makes it impossible to form a RAS from premature infants' perspective. It is understood that childcare maintenance, carried out with both a physician and a nurse, in PHC, contributes to the programmatic care of chronic conditions and (re)orientation of services in cases of acute conditions.

\section{REFERENCES}

1. Mendes EV. As redes de atenção à saúde. Brasília: Organização Pan-Americana da Saúde [Internet]. 2011 [cited 2020 Apr 15];549 p. Available from: https://www.paho.org/bra/index.php?option=com_docman\&view=download\&category_slug=servicos-saude-095\&alias=1402-asredes-atencao-a-saude-2a-edicao-2\&ltemid=965

2. Fertonani HP, Pires DEP, Biff D, Scherer MGA. The health care model: concepts and challenges for primary health care in Brazil. Ciênc Saúde Coletiva. 2015;20(6):1869-78. https://doi.org/10.1590/1413-81232015206.13272014

3. Santiago ACT, Moreira LMO, Lyra PR, Alves C. Perfil de crescimento de recém-nascidos prematuros menores de 32 semanas no primeiro ano de vida. Rev Ciênc Méd. Biol. 2014;13(3):269-73. https://doi.org/10.9771/cmbio.v13i3.12935

4. Moreira RS; Magalhães LC, Alves CRL. Effect of preterm birth on motor development, behavior, and school performance of school-age children: a systematic review. J Pediatr (Rio J.) 2014;90(2):119-34. https://doi.org/10.1016/j.jped.2013.05.010

5. Martínez LA, Fernández CEM, Álvarez RPG, Llorente A. Consumo de recursos sanitarios en atención primaria de los prematuros tardíos: estudio caso-control en un centro de salud urbano. An Pediatr. 2015;83(3):213-5. https://doi.org/10.1016/j.anpedi.2015.03.002

6. Oliveira LL, Gonçalves AC, Costa JSD, Bonilha ALL. Maternal and neonatal factors related to prematurity. Rev Esc Enferm USP. 2016;50(3):3829. https://doi.org/10.1590/S0080-623420160000400002

7. Silva MEA, Reichert APS, Souza SAF, Pimenta EAG, Collet N. Chronic disease in childhood and adolescence: family bonds in the healthcare network. Texto Contexto Enferm. 2018;27(2):e4460016. https://doi.org/10.1590/0104-070720180004460016

8. Nóbrega VM, Silva MEA, Fernandes LTB, Viera CS, Reichert APS, Collet N. Chronic disease in childhood and adolescence: continuity of care in the Health Care Network. Rev Esc Enferm USP. 2017; 51:e03226. https://doi.org/10.1590/S1980-220X2016042503226

9. Pastura PSVC, Paiva CG. Transition to adult health care for adolescents with chronic conditions: practices of a tertiary care hospital in Brazil. Rev Ped SOPERJ. 2018;18(2):3-10. https://doi.org/10.31365/issn.2595-1769.v18i2p3-10

10. Fernandes LTB, Nóbrega VM, Silva MEA, Machado AN, Collet N. Supported self-care for children and adolescents with chronic disease and their families. Rev Bras Enferm. 2017;70(6):1318-29. https://doi.org/10.1590/0034-7167-2016-0553

11. Organização Pan-Americana da Saúde (OPAS). A atenção à saúde coordenada pela APS: construindo as redes de atenção no SUS: contribuições para o debate Brasília: OPAS [Internet]. 2011 [cited 2020 Apr 15]. Available from: https://iris.paho.org/handle/10665.2/18457

12. Solano LC, Lacerda VS, Miranda FAN, Ferreira JKA, Oliveira KKD, Leite AR. Coordination of care for premature newborns: challenges for primary health care. Rev Min Enferm. 2019;23:e-1168. https://doi.org/10.5935/1415-2762.20190016

13. Tong A, Sainsbury P, Craig J. Consolidated criteria for reporting qualitative research (COREQ): a 32-item checklist for interviews and focus groups, Int J Qual Health Care. 2007;19(6):349-57. https://doi.org/10.1093/intqhc/mzm042

14. Prefeitura Municipal de Santa Maria. Relatório físico financeiro e de gestão de indicadores anual. [Internet]. 2015 [cited 2018 Aug 15 ]. Available from: https://www.santamaria.rs.gov.br/docs/noticia/2015/03/D18-805.pdf

15. Engle WA. A recommendation for the definition of "late preterm" (near-term) and the birth weight-gestational age classification system. Semin Perinatol. 2006;30(1):2-7. https://doi.org/10.1053/j.semperi.2006.01.007

16. Fontanella BJB, Ricas J, Turato ER. Amostragem por saturação em pesquisas qualitativas em saúde: contribuições teóricas. Cad Saúde Pública. 2008;24(1):17-27. https://doi.org/10.1590/\$0102-311X2008000100003

17. Starfield B. Atenção Primária: equilíbrio entre necessidades de saúde, serviços e tecnologia. Brasília: UNESCO, Ministério da Saúde; 2002.726 p.

18. Bardin L. Análise de conteúdo. São Paulo: Edições 70; 2011, 229p.

19. Ministério da Saúde (BR). Secretaria de Atenção à Saúde. Departamento de Atenção Básica. Saúde da criança: crescimento e desenvolvimento/Ministério da Saúde. Secretaria de Atenção à Saúde. Departamento de Atenção Básica. Brasília: Ministério da Saúde; 2012. 272 p. (Cadernos de Atenção Básica, n 33).

20. Breivold K, Hjaelmhult E, Sjöström-Strand A, Hallström IK. Mothers' experiences after coming home from the hospital with a moderately to late preterm infant : a qualitative study. Scandin J Caring Sci. 2019;33(3):632-40. https://doi.org/10.1111/scs.12656

21. Casey PH, Irby C, Withers S, Dorsey S, Li J, Rettiganti M. Home visiting and the health of preterm infants. Clin Pediatr. 2017;56(9):828-37. https://doi.org/10.1177/0009922817715949

22. Goh LH, Choon HH, Kar HN. Failure to thrive in babies and toddlers. Singapore Med J. 2016; 57(6):287-91. https://doi.org/10.11622/ smedj.2016102 
23. Vieira DS, Santos NCCB, Nascimento JA, Toso BRGO, Reichert APS. Nursing practices in child care consultation in the Estratégia Saúde da Família. Texto Contexto Enferm. 2018;27(4):e4890017. https://doi.org/10.1590/0104-07072018004890017

24. Silva MEA, Moura FM, Albuquerque TM, Reichert APS, Collet N. Network and social support in children with chronic diseases: understanding the child's perception. Texto Contexto Enferm. 2017;26(1):e6980015. https://doi.org/10.1590/0104-07072017006980015

25. Tangcharoensathien V, Kunihiko CH, Chompoonut T, Shaheda V, Orana C, Walaiporn P. Children and Women's Health in South East Asia: Gap Analysis and Solutions. Int J. Environ. Res. Public Health. 2020, 17, 3366. https://doi.org/10.3390/ijerph17103366

26. Aires LCP, Santos EKA, Bruggemann OM, Backes MTS, Costa R. Reference and counter-reference health care system of infant discharged from neonatal unit: perceptions of primary care health professionals. Esc Anna Nery. 2017;21(2):e20170028. https://doi. org/10.5935/1414-8145.20170028

27. Duarte ED, Tavares TS, Cardoso IVL, Vieira CS, Guimarães BR, Bueno M. Factors associated with the discontinuance of outpatient follow-up in neonatal units. Rev Bras Enferm. 2020;73(3):e20180793. https://doi.org/10.1590/0034-7167-2018-0793

28. Braga PP, Sena RR. Devir cuidadora de prematuro e os dispositivos constituintes da continuidade da atenção pós-alta. Texto Contexto Enferm. 2017;26(3):e3070016. https://doi.org/10.1590/0104-07072017003070016

29. Silva RMM, Zilly A, Nonose ERS, Fonseca LMM, Mello DF. Care opportunities for premature infants: home visits and telephone support. Rev Latino-Am Enfermagem 2020;28:e3308. https://doi.org/10.1590/1518-8345.3520.3308 